\title{
Acid Hydrolysis of Tetraphenylborate at Elevated Temperature and Pressure
}

by

J. R. Fowler

E. l. du Pont de Nemours and Company

Savannah River Site

Aiken, South Carolina 29808

\section{MASTER}

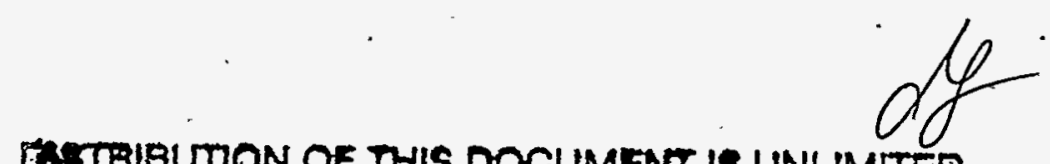

EMTRRIBUTION OF THIS DOCUMENT IS UNLMMTIDD

DOE Contract No.

This paper was prepared in connection with work done under the above contract number with the U.S.

Department of Energy. By acceptance of this paper, the publisher and/or recipient acknowledges the U. S. Government's right to retain a nonexclusive, royalty-free license in and to any copyright covering this paper, along with the right to reproduce and to authorize others to reproduce all or part of the copyrighted paper. 


\section{DISCLAIMER}

This report was prepared as an account of work sponsored by an agency of the United States Government. Neither the United States Government nor any agency thereof, nor any of their employees, makes any warranty, express or implied, or assumes any legal liability or responsibility for the accuracy, completeness, or usefulness of any information, apparatus, product, or process disclosed, or represents that its use would not infringe privately owned rights. Reference herein to any specific commercial product, process, or service by trade name, trademark, manufacturer, or otherwise does not necessarily constitute or imply its endorsement, recommendation, or favoring by the United States Government or any agency thereof. The views and opinions of authors expressed herein do not necessarily state or reflect those of the United States Government or any agency thereof.

This report has been reproduced directly from the best available copy.

Available to DOE and DOE contractors from the Office of Scientific and Technical Information, P.O. Box 62, Oak Ridge, TN 37831; prices available from (615) 576-8401.

Available to the public from the National Technical Information Service, U.S. Department of Commerce, 5285 Port Royal Road, Springfield, VA 22161. 


\section{DISCLAIMER}

\section{Portions of this document may be illegible electronic image products. Images are produced from the best available original document.}




$$
721
$$

TECHNICAI DIVISION

SAVANNAH RIVER LABORATORY

\section{REVISED}

DPST-82-555

CC: A.C.NO, 148257
H. H. Kelley, SRI
R. B. Ferguson
M. J. Plodinec
I. L. Rilpatrick
I. M. Lee
TIS File Copy (2)

May 27,1982

TO: I. M. PAPOUCHADO

FROM: J. R. FOWLER

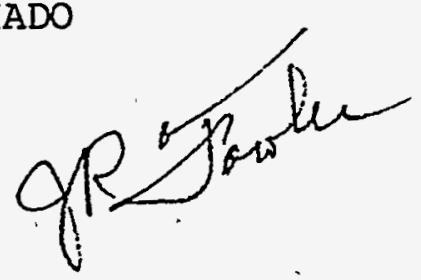

TIS FILE
RECORD COPY

ACID HYDROLYSIS OF TETRARHENYIBORATE

AT ELEVATED TEMPERATURE AND PRESSURE

\section{Introduction}

Sodium tetraphenylborate is used to coprécipitate cesium with potassium in the precipitation process that has been developed to decontaminate waste salt solutions. However, the high organic content of the resulting precipitate prevents direct addition of this precipitate to melter feed containing waste sludge because the level of organic compounds is sufficiently high to. reduce many of the waste components to metals. To eliminate this potential problem, three alternatives exist:

1. Remove the organic content from the precipitate by decomposing the tetraphenylborate salts,

2. Incorporate the tetraphenylborate precipitate into a "cesium only" glass; or

3. Use the precipitate to produce gamma sources or heat sources based on $\mathrm{Cs}-137$.

of these thrée choices, decomposition of tetraphenylborate salts is preferred if an acceptable process can be developed. 
Methods to decompose tetraphenylborate are being investigated by several workers. At my request, T. A. Koch and R. S. Boucher. of Petrochemicals Central Research have investigated hydrolysis of potassium tetraphenylborate: Their assistance was requested because of their familiarity with chemical reactions run at elevated temperature and pressure. The equipment and analytical capabilities required for these experiments are also readily available at their laboratory. This report summarizes the results that they have obtained.

\section{SUMMARY}

Hydrolysis of tetraphenylboraté salts to benzene and inorganic borate. is best done at low $\mathrm{pH}(1-4)$. Oxygen must be excluded during hydrolysis to avoid undesirable reaction products (phenol, biphenyl). The best results were obtained using these conditions:

1. potassium tetraphenylborate slurried in water was acidified with formic acid (approximately 8 moles $\mathrm{HCOOH} / \mathrm{mole}$ of tetraphenylborate);

2. oxygen was excluded from the reaction mixture by, sparging with nitrogen;

3. the reaction vessel was pressurized to 25 lbs. pisig with nitrogen gas;

4. the reaction mixture was heated to $125^{\circ} \mathrm{C}$ to hydrolyze tetraphenylborate ( $70 \mathrm{psig}$ at temperature.)

After heating 2 hrs. at $125^{\circ} \mathrm{C}$ and 70 psig, the mixture was cooled and reaction products were analyzed. Iess than 0.18 of the original potassium tetraphenylborate remained in the reaction mixture. Based on the benzene balance for the mixture, approximately $5 \%$ of the theoretical yield for benzene is present as phenylboric acid $\left[\left(\mathrm{C}_{6} \mathrm{H}_{5}\right) \mathrm{B}\left(\mathrm{OH}_{2}\right)_{2}\right]$. The level of bipheny 1 was at the detection limit in the reaction mixture (approximately $0.0028)$. Phenylborate esters, observed in other reactions, did not appear to be present in this reaction mixture. This reaction was run using a slurry containing only potassium tetraphenylborate. No other salts or sodium titanate were present.

The reaction was repeated using the KTPB/sodium titanate simulated slurry that we supplied to confirm that these reaction conditions are suitable for our slurry composition: This reaction also proceeded smoothly. A similar product distribution was obtained. In a separate experiment, benzene was allowed to "bleed". out of the reaction vessel as the reaction proceeded. The removal 
of benzene as the reaction proceeded did not appear to affect the product distribution.

A simplified flowsheet for hydrolysis of tetraphenylborate based on these results is shown in Figure 1 . The benzene stripping operation could. conceivably be done in the slurry mixer evaporator in stage 1 of the DWPF.

A summary of all the reactions are shown in Table $I$. Appropriate chemical reactions for the best process are shown in Table II. These reactions provide a basis for material balance for the hydrolysis retactions. They do not necessarily reflect the mechanism by which hydrolysis proceeds.

The experiments that we requested are completed. The results provide a basis for a decomposition process based on hydrolysis of TPB. Because of these promising results, I recommend that we install an autoclave to establish specific requirements for a deomposition process based on hydrolysis of TPB at elevated temperature and pressure.

JRF : pme

Att

Disc 4 
TABLE I

A SUMMARY OF REACTION CONDITIONS FOR HYDROLYSIS OF TETRAPHENYLBORATE (TPB)

$\mathrm{pH}$

Temperature

$320^{\circ} \mathrm{C}$

+

1 ( $\mathrm{HCl}$

$150^{\circ} \mathrm{C}$

$1\left(\mathrm{HNO}_{3}\right)$

$150^{\circ} \mathrm{C}$

$2-3(\mathrm{HCOOH}) 125^{\circ} \mathrm{C}$
3000 psig

90 psig

90 psig

Pressure

psig

.

70 psig
Comments

Base stablizes TPB. 2

hrs. hydrolysis

converted approximateily 808 TPB to benzene. No phenol or biphenyl

detected. Trace of phenylboric acid detected (sodium salt).

No TPB detected. Formation of trimeric borate ester oil observed (insoluble in $\mathrm{H}_{2} \mathrm{O}$ ). Ester is condensation product of phenylboric acid.

No TPB detected. Phenol detected qualitatively. Trimeric borate ester oil observed. Some nitration of benzerie or phenol may have occurred, based on dark color of benzene layer.

Hydrolysis proceeded smoothly with both IPB and simulated slurry. Specific results summarized in body of report. 

L. M. PAPOUCHADO

\section{TABLE II}

CHEMICAL REACTIONS FOR ACID HYDROLYSIS OF TETRAPHENYLBORATE'

$\mathrm{NaOH}+\mathrm{HCOOH} \longrightarrow \mathrm{NaCOOH}+\mathrm{H}_{2} \mathrm{O}$

\section{Benzene}

$$
\mathrm{M} *\left[\mathrm{~B}\left(\mathrm{C}_{6} \mathrm{H}_{5}\right)_{4}\right]+3 \mathrm{H}_{2} \mathrm{O} \stackrel{\mathrm{H}^{+}}{\longrightarrow} \mathrm{MH}_{2} \mathrm{BO}_{3}+\mathrm{C}_{6} \mathrm{H}_{6}
$$

Benzene + Phenol

$$
\mathrm{M} *\left[\mathrm{~B}\left(\mathrm{C}_{6} \mathrm{H}_{5}\right)_{4}\right]+3 \mathrm{H}_{2} \mathrm{O}+1 / 2 \mathrm{O}_{2} \stackrel{\mathrm{H}^{+}}{\longrightarrow} \mathrm{MH}_{2} \mathrm{BO}_{3}+3 \mathrm{C}_{6} \mathrm{H}_{6}
$$

\section{Benzene + BiphenyI}

$$
\mathrm{M} *\left[\mathrm{~B}\left(\mathrm{C}_{6} \mathrm{H}_{5}\right)_{4}\right]+2 \mathrm{H}_{2} \mathrm{O}+1 / 2 \mathrm{O}_{2} \stackrel{\mathrm{H}^{+}}{\longrightarrow} \mathrm{MH}_{2} \mathrm{BO}_{3}+2 \mathrm{C}_{6} \mathrm{H}_{6}+\left(\mathrm{C}_{6} \mathrm{H}_{5}\right)_{2}
$$

* $\mathrm{M}=\mathrm{Na}, \mathrm{K}, \mathrm{Cs}, \mathrm{Rb}, \mathrm{Fr}$

a. These reactions provide a basis for material balance in the hydrolysis
process. They do not reflect the mechanism by which hydrolysis proceeds. 


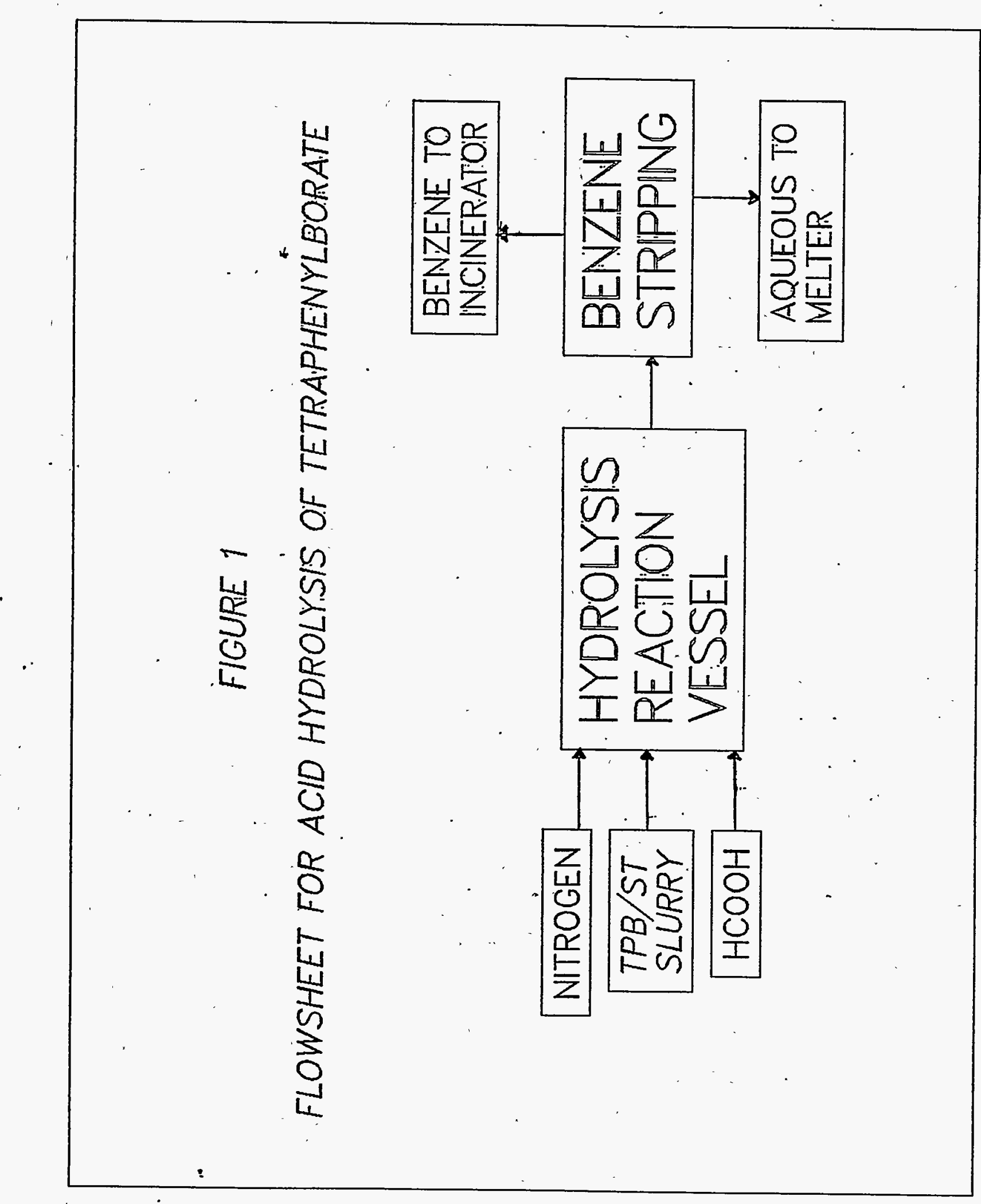

